\title{
Recyclable L-proline organocatalyst for Wieland-Miescher ketone synthesis
}

\author{
VIVEK SRIVASTAVA \\ Applied Science, NIIT University, NH-8 Delhi-Jaipur Highway, Neemrana, Distt., Alwar 301 705, India \\ e-mail: vivek.srivastava.chem@gmail.com
}

MS received 23 April 2013; revised 3 September 2013; accepted 5 September 2013

\begin{abstract}
Wieland-Miescher ketone $\mathbf{4}$ was synthesised using L-proline catalyst in the ionic liquid medium via non-selective conjugated addition reaction followed by an enantioselective intermolecular Aldol condensation reaction of triketone 3 intermediate. Short reaction time, recycling of the catalyst, good yield and selectivity are major outcomes of this proposed protocol.
\end{abstract}

Keywords. L-proline; ionic liquid; Wieland-Miescher ketone.

\section{Introduction}

Wieland-Miescher ketone analogues are very useful building blocks to synthesise various biologically active compounds such as steroids, terpenoids and taxol. ${ }^{1}$ Wieland-Miescher ketone analogues can be synthesized via two different methods (Hajos-Parrish-EderSauer-Wiechert reaction and Robinson annulation reaction). ${ }^{1}$ Various catalysts such as antibody $38 \mathrm{C} 2(96 \%$ ee), ${ }^{2 \mathrm{a}} \beta$-amino acid $(1 R, 2 S)$-cispentacin $(86 \% \mathrm{ee}),{ }^{2 \mathrm{~b}}$ prolinethiomides $(86 \%$ ee $),{ }^{2 c}$ etc. were tested to improve the yield and stereoselectivity of the WielandMiescher ketone analogue synthesis. ${ }^{1 \mathrm{~b}}$ Hanessian et al documented that cis-(2S, 4S, 5S)-4, 5-methanoproline as an alternative catalyst of L-proline, offers the Wieland-Miescher ketone analogues with 93\% enantiomeric excess along with good yield, whereas catalysis with trans-( $2 S, 4 S, 5 S)-4,5$-methanoproline proceeded at much slower rate than L-proline and offers enone with lower selectivity $(83 \%$ ee $){ }^{3}$ There are relatively few examples where primary amino acids were used as enantioselective catalyst for this reaction such as L-phenylalanine gave $(S)$ enone $85 \%$ yield with $25 \%$ e.e., while L-tert-leucine offers $(S)$-ketone with higher yield (95\%) but lesser enantiomeric excess (only 2\%). ${ }^{4 \mathrm{a}}$ Various proline derivatives such as D-proline (6 days, $82 \%$ yield), L-proline (5 days, $56 \%$ yield) etc. were also tested with or without solvent system to catalyse the Wieland-Miescher ketone synthesis. ${ }^{4 \mathrm{~b}-\mathrm{h}}$ Despite these numerous investigations, L-proline remains the most interesting catalyst known for this reaction ${ }^{4 \mathrm{~b}-\mathrm{h}, 5}$ (scheme 1), but along with L-proline and other alternative organocatalysts for Wieland-Miescher ketone analogues synthesis suffers from several drawbacks such as long reaction time, high catalyst loading, low catalyst solubility, requirement of polar solvents (Dimethyl sulfoxide (DMSO) and Dimethylformamide (DMF)), costly starting materials for catalyst synthesis, tedious work-up procedure at product isolation step, etc. Various protocols along with ionic liquids, have been reported by different groups time to time in order to overcome the above mentioned demerits of organocatalysed reactions. ${ }^{6,7}$ Kodo et al. studied polymer bound $(S)$-proline as catalyst ${ }^{8}$ while Agami et al. described proline catalysed aldol-cyclodehydrations of acyclic diketones. ${ }^{9} D$-phenylanaline and $D$-camphorsulfonic acid was tested in $[\mathrm{hmim}] \mathrm{PF}_{6}$ along with dimethylimidazolidinone was tested for Wieland-Miescher ketone analogues synthesis. ${ }^{10}$ Although, $81 \%$ yield and $74 \%$ ee

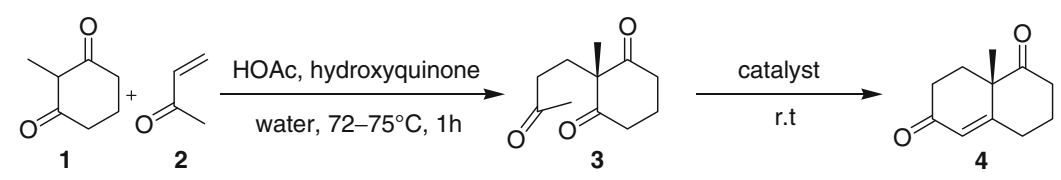

Scheme 1. Two-step synthesis of Wieland-Miescher ketone 4. 
along with five times recycling of the catalytic system were the major outcomes of this process, the proposed protocol suffers high catalyst loading, requirement of polar solvent (as co-solvent), longer reaction time and continuous drop in yield and selectivity during recycling of the catalytic system, etc.

In this report, we optimized the reaction conditions of the L-proline-catalysed Wieland-Miescher ketone 4 synthesis. During the reaction, L-proline was found active, recoverable and relatively inexpensive in $\left[\mathrm{pyC}_{4}\right]$ $\mathrm{NTf}_{2}$ with respect to conventional solvents. High polarity of ionic liquid is expected to work as an activating and stabilizing solvent for the L-proline to catalyse Wieland-Miescher ketone 4.

\section{Experimental}

All the chemicals were purchased from Sigma Aldrich and SD fine chemicals. Commercially supplied reagents were used as provided. Organic solvents were dried up as per their specifications. The work-up and purification procedure were carried out with reagent-grade solvents. Nuclear magnetic resonance (NMR) spectra were recorded on standard Bruker 300WB spectrometer with an Avance console at 300 and $75 \mathrm{MHz}$ for ${ }^{1} \mathrm{H}$ and ${ }^{13} \mathrm{C}$ NMR, respectively. Enantiomeric excesses were determined by chiral-phase HPLC: Waters 600E System Controller and a Waters 996 Photodiode Array Detector Column with Chiralcel OD-H column from Daicel Chemical Industries Ltd., eluting with n-hexane and ethyl acetate. Ionic liquids were synthesised as per their standard reported procedure. ${ }^{11}$ The detailed ${ }^{1} \mathrm{H}$ NMR and ${ }^{13} \mathrm{C}$ NMR were found similar as per reported data. $^{7}$

\subsection{General experimental procedure}

\section{1a 2-Methyl-2-(3-oxobutyl)-1,3-cyclohexanedione} or triketone 3: A $100 \mathrm{~mL}$, round-bottomed flask equipped with a thermometer and a reflux condenser capped with an argon-inlet tube was charged with $1.26 \mathrm{~g}$ (10 mmol) of 2-methylcyclohexane-1, 3-dione $\mathbf{1}$ and $10 \mathrm{~mL}$ of distilled water. To the well-stirred suspension were added $0.023 \mathrm{~mL}$ of acetic acid, $0.008 \mathrm{~g}$ of hydroquinone and $1.42 \mathrm{~g}(20 \mathrm{mmol})$ of freshly distilled methyl vinyl ketone 2 . The reaction mixture was stirred under argon at $72-75^{\circ} \mathrm{C}$ for $1 \mathrm{~h}$, cooled to room temperature, treated with sodium chloride $(1.03 \mathrm{~g})$, and poured into a separatory funnel containing ethyl acetate $(4 \times 5 \mathrm{~mL})$. The organic phase was collected and aqueous phase was extracted twice with ethyl acetate
( $2 \mathrm{~mL}$ each time). The combined extracts were further washed with two $20 \mathrm{~mL}$ portions of saturated brine, dried over anhydrous magnesium sulphate, filtered, and concentrated. The residue was further purified via column chromatography using ethyl acetate and the hexane mixture (1:2) which offers the titled product 3 as pale-yellow oil in good yield (1.78 g, 97\% yield). ${ }^{1} \mathrm{H}$ NMR $\left(300 \mathrm{MHz}, \mathrm{CDCl}_{3}\right)$ 2.53-2.78 (m, 4H), 2.23$2.38(\mathrm{~m}, 2 \mathrm{H}), 2.09$ (s, 3H), 1.81-2.07 (m, 4H), 1.22 (s, 3H). ${ }^{13} \mathrm{C}$ NMR $\left(75 \mathrm{MHz}, \mathrm{CDCl}_{3}\right)$ 17.8, 20.2, 29.7, 30.1, 37.9, 38.5, 64.5, 207.7, 210.2.

2.1b (S)-8a-Methyl-3, 4, 8, 8-tetrahydro-1, 6 (2H, 7H)-naphthalen edione (3-S) (4): $50 \mathrm{~mL}$, one-necked, round-bottomed flask, was charged with L-proline $(0.5-1.5 \mathrm{~mol} \%)$ or other catalyst and a solution of 2-methyl-2-(3-oxobutyl)-1,3-cyclohexanedione $\mathbf{3}$ $(1 \mathrm{mmol})$ in ionic liquid $(1-3 \mathrm{~mL})$ or organic solvent $(2 \mathrm{~mL})$ or water $(2 \mathrm{~mL})$. The mixture was allowed to stir at room temperature for $2 \mathrm{~h}$. Further, volatile organic materials was evaporated from the reaction slurry under vacuum. The reaction product was further extracted with diethyl ether $(5 \times 2 \mathrm{~mL})$ by vigorous stirring followed by decantation of the upper diethyl ether layer. Evaporation of the combined organic layer and the subsequent medium pressure-filtration chromatography (FC) purification of residue (eluent: AcOEt: $n$-hexane $=1: 3)$ offered the titled product 4. A new portion of reactants was added to recycle the catalytic system. ${ }^{1} \mathrm{H}$ NMR $\left(300 \mathrm{MHz}, \mathrm{CDCl}_{3}\right)$ $1.43(\mathrm{~s}, 3 \mathrm{H}), 1.60-1.77(\mathrm{~m}, 2 \mathrm{H}), 2.06-2.19(\mathrm{~m}, 3 \mathrm{H})$, 2.40-2.53 (m, 4H), 2.63-2.77 (m, 2H), $5.83(\mathrm{~d}, J=$ $1.8 \mathrm{~Hz}, 1 \mathrm{H}) .{ }^{13} \mathrm{C}$ NMR $\left(75 \mathrm{MHz}, \mathrm{CDCl}_{3}\right) 23.5,23.9$, 30.2, 32.4, 34.2, 38.3, 51.2, 126.4, 166.5, 199, 211.7. $[\alpha]_{\mathrm{D}}^{20}+1.8\left(c=1.2, \mathrm{CHCl}_{3}\right)$, HPLC Chiral OD-H, Hexanes/IPrOH 90/10, $0.5 \mathrm{~mL} \cdot \mathrm{min}^{-1}$, minor $t=$ $40.7 \mathrm{~min}$, major $t=31.0 \mathrm{~min}$.

\section{Result and discussion}

Synthesis of Wieland-Miescher ketone $\mathbf{4}$ proceeds via non-selective conjugated addition reaction followed by an enantioselective intermolecular Aldol condensation reaction of triketone $\mathbf{3}$ intermediate. The intermediate, triketone $\mathbf{3}$ was synthesised as per reported procedure by the reaction between methyl vinyl ketone 2 and 2-methylcyclohexane-1, 3-dione 1. ${ }^{1,2}$ The isolated yield of triketone 3 was $97 \%$. The identity of the intermediate triketone 3 was confirmed by ${ }^{1} \mathrm{H}$ NMR and ${ }^{13} \mathrm{C}$ NMR (scheme 2). Later structurally confirmed, triketone $\mathbf{3}$ was used for the synthesis of WielandMiescher ketone $\mathbf{4}$ under different reaction conditions, 


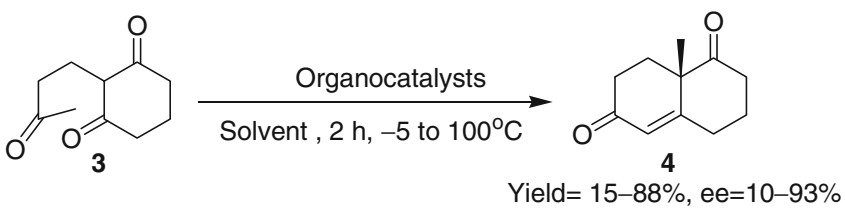

Scheme 2. Organocatalysts/ionic liquid catalytic system for Wieland-Miescher ketone 4 synthesis under different parameters.

in order to achieve the best results with respect to yield and sterioselectivity.

We tested a series of ionic liquids with L-proline ( $1 \mathrm{~mol} \%$ ) as per scheme 3 and the corresponding results are summarised in table 1, entries 1-6.

Surprisingly, Wieland-Miescher ketone $\mathbf{4}$ was obtained in good yield (42-88\%) and selectivity (61$93 \%$ ) with L-proline (table 1, scheme 2) in different ionic liquids. Higher yield (88\%) and selectivity $(93 \%$ ee) was found only with $\left[\mathrm{pyC}_{4}\right] \mathrm{NTf}_{2}$ reaction medium. After obtaining good catalytic activity of L-proline in $\left[\mathrm{PyC}_{4}\right] \mathrm{NTf}_{2}$ with respect to yield and selectivity, we further studied various other reaction parameters such as time, temperature, catalyst loading, solvents such as $\mathrm{N}, \mathrm{N}$-dimethylformamide (DMF), dimethyl sulphoxide (DMSO), $N$-methylpyrrolidine (NMP), tetrahydrofuran (THF), dichloromethane (DCM) and water. All the results were summarised in table 2, entries 1-21.

Lower yield and selectivity (table 2 , scheme 2 , entry 2) was obtained with smaller quantity $(0.50 \mathrm{~mol} \%)$ of L-proline, while the higher quantity of the L-proline ( $1.5 \mathrm{~mol} \%$, table 2 , entry 3$)$ gave almost similar results as we obtained from $1 \mathrm{~mol} \%$ of L-proline (table 2 , entry 1 ) in $\left[\mathrm{pyC}_{4}\right] \mathrm{NTf}_{2}$. Temperature parameters were

Table 1. Screening of L-proline with different ionic liquids for Wieland-Miescher ketone $\mathbf{4}$ synthesis.

\begin{tabular}{|c|c|c|c|}
\hline \multirow[b]{2}{*}{ Entry } & \multirow[b]{2}{*}{ Ionic liquid $(2 \mathrm{~mL})$} & \multicolumn{2}{|c|}{ Results } \\
\hline & & Yield $(\%)^{1}$ & ee $(\%)^{2}$ \\
\hline 1 & {$[\mathrm{bmim}]\left[\mathrm{PF}_{6}\right]$} & 68 & 65 \\
\hline 2 & {$\left[\mathrm{pyC}_{4}\right]\left[\mathrm{PF}_{6}\right]$} & 42 & 73 \\
\hline 3 & {$[\mathrm{tmba}]\left[\mathrm{PF}_{6}\right]$} & 28 & 61 \\
\hline 4 & {$[\mathrm{bmim}]\left[\mathrm{NTf}_{2}\right]$} & 76 & 78 \\
\hline 5 & {$\left[\mathrm{pyC}_{4}\right]\left[\mathrm{NTf}_{2}\right]$} & 88 & 93 \\
\hline 6 & {$[\mathrm{tmba}]\left[\mathrm{NTf}_{2}\right]$} & 74 & 74 \\
\hline
\end{tabular}

${ }^{1}$ Isolated yields after column chromatography

${ }^{2}$ Determined by HPLC

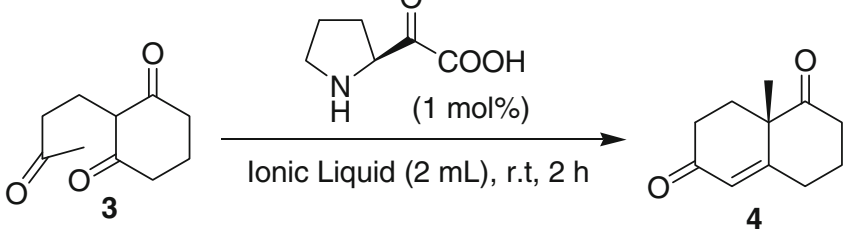

Scheme 3. L-proline/ionic liquid catalytic system for Wieland-Miescher ketone $\mathbf{4}$ synthesis.

also optimised (from $-5^{\circ} \mathrm{C}$ to $100^{\circ} \mathrm{C}$ ) (table 2, entries 4-7) for Wieland-Miescher ketone 4 synthesis and it was concluded that at higher temperature L-proline gets decomposed and offers lower yield and selectivity. Lowering the reaction temperature from $0^{\circ}$ to $-5^{\circ} \mathrm{C}$ was also not found suitable in terms of yield and selectivity for Wieland-Miescher ketone $\mathbf{4}$ synthesis (table 2, entries 8-9). No reaction was found at $-5^{\circ} \mathrm{C}$ as the reaction mass gets solidified. Screening conventional organic solvents such as DMF, DMSO, NMP, THF, DCM and water for Wieland-Miescher ketone 4, was the other major goal of our study in order to understand the behaviour of L-proline catalysts for WielandMiescher ketone 4 synthesis (table 2, entries 10-15). While decreasing the polarity of the solvent, the corresponding yield of the Wieland-Miescher ketone 4 also decreased from $35 \%$ to $67 \%$ and selectivity was found to be between $45 \%$ and $69 \%$. In DMSO solvent system with L-proline, Wieland-Miescher ketone responded with $67 \%$ yield and $65 \%$ ee (table 2, entry 11). Under solventless condition, L-proline also offered the Wieland-Miescher ketone $\mathbf{4}$ in acceptable yield and selectivity (48\% yield, 67\% ee) (table 2, entry 16 ). Apart from L-proline, we also tested other alternative catalysts for Wieland-Miescher ketone 4 synthesis with [pyC4] $\mathrm{NTf}_{2}$ (table 2, entries 17-21) but no such significant increase in yield and selectivity was observed.

To evaluate the possibility of recycling the ionic liquid mediated L-proline catalytic system for Wieland-Miescher ketone $\mathbf{4}$ synthesis, triketone $\mathbf{3}$ was allowed to react with $\left[\mathrm{pyC}_{4}\right] \mathrm{NTf}_{2}$ immobilised Lproline catalyst and the corresponding product was then extracted with diethyl ether $(5 \times 2 \mathrm{~mL})$ (scheme 4$)$. A second amount of triketone $\mathbf{3}$ was added to the previously used $\left[\mathrm{pyC}_{4}\right] \mathrm{NTf}_{2}$ immobilised L-proline catalytic system and the process was repeated up to eight times. Surprisingly, there was no significant loss in yield (85$88 \%$ ) and selectivity (90-93\% ee) was observed during the eight recycling runs of L-proline/[pyC $\left.\mathrm{p}_{4}\right] \mathrm{NTf}_{2}$ catalytic system during the Wieland-Miescher ketone $\mathbf{4}$ synthesis (figure 1). 
Table 2. Screening reaction parameters for Wieland-Miescher ketone 4 synthesis.

\begin{tabular}{|c|c|c|c|c|c|}
\hline Entry & Solvent $(2 \mathrm{~mL})$ & Catalyst & $T /{ }^{\circ} \mathrm{C}$ & Yield $(\%)^{1}$ & ee $(\%)^{2}$ \\
\hline 1 & {$\left[\mathrm{pyC}_{4}\right]\left[\mathrm{NTf}_{2}\right]$} & L-proline (1 mol \%) & $\mathrm{rt}$ & 88 & 93 \\
\hline 2 & {$\left[\mathrm{pyC}_{4}\right]\left[\mathrm{NTf}_{2}\right]$} & L-proline $(0.5 \mathrm{~mol} \%)$ & $\mathrm{rt}$ & 67 & 66 \\
\hline 3 & {$\left[\mathrm{pyC}_{4}\right]\left[\mathrm{NTf}_{2}\right]$} & L-proline $(1.5 \mathrm{~mol} \%)$ & $\mathrm{rt}$ & 75 & 79 \\
\hline 4 & {$\left[\mathrm{pyC}_{4}\right]\left[\mathrm{NTf}_{2}\right](1 \mathrm{~mL})$} & L-proline $(1 \mathrm{~mol} \%)$ & $\mathrm{rt}$ & 72 & 79 \\
\hline 5 & {$\left[\mathrm{pyC}_{4}\right]\left[\mathrm{NTf}_{2}\right](3 \mathrm{~mL})$} & L-proline (1 mol \%) & $\mathrm{rt}$ & 78 & 81 \\
\hline 6 & {$\left[\mathrm{pyC}_{4}\right]\left[\mathrm{NTf}_{2}\right]$} & L-proline (1 mol \%) & 100 & 15 & 75 \\
\hline 7 & {$[\mathrm{tmba}]\left[\mathrm{NTf}_{2}\right]$} & L-proline (1 mol \%) & 50 & 38 & 78 \\
\hline 8 & {$[\mathrm{tmba}]\left[\mathrm{NTf}_{2}\right]$} & L-proline (1 mol \%) & -5 & nd & - \\
\hline 9 & {$[\mathrm{tmba}]\left[\mathrm{NTf}_{2}\right]$} & L-proline (1 mol \%) & 0 & 25 & 54 \\
\hline 10 & DMF & L-proline (1 mol \%) & $\mathrm{rt}$ & 63 & 69 \\
\hline 11 & DMSO & L-proline (1 mol \%) & $\mathrm{rt}$ & 67 & 65 \\
\hline 12 & NMP & L-proline (1 mol \%) & $\mathrm{rt}$ & 55 & 67 \\
\hline 13 & $\mathrm{THF}$ & L-proline (1 mol \%) & $\mathrm{rt}$ & 40 & 69 \\
\hline 14 & DCM & L-proline (1 mol \%) & $\mathrm{rt}$ & 35 & 49 \\
\hline 15 & Water & L-proline (1 mol \%) & $\mathrm{rt}$ & 37 & 45 \\
\hline 16 & Neat & L-proline $(1 \mathrm{~mol} \%)$ & $\mathrm{rt}$ & 48 & 67 \\
\hline 17 & {$\left[\mathrm{pyC}_{4}\right]\left[\mathrm{NTf}_{2}\right]$} & L-hydroxyproline (1 mol \%) & $\mathrm{rt}$ & 65 & 74 \\
\hline 18 & {$\left[\mathrm{pyC}_{4}\right]\left[\mathrm{NTf}_{2}\right]$} & (S)-phenylanaline $(1 \mathrm{~mol} \%)$ & $\mathrm{rt}$ & 48 & 68 \\
\hline 19 & {$\left[\mathrm{pyC}_{4}\right]\left[\mathrm{NTf}_{2}\right]$} & 2-(S)-trans-4-hydroxyproline (1 mol \%) & $\mathrm{rt}$ & 15 & 58 \\
\hline 20 & {$\left[\mathrm{pyC}_{4}\right]\left[\mathrm{NTf}_{2}\right]$} & (S)-proline ethyl ester $(1 \mathrm{~mol} \%)$ & $\mathrm{rt}$ & 25 & 10 \\
\hline 21 & {$\left[\mathrm{pyC}_{4}\right]\left[\mathrm{NTf}_{2}\right]$} & (S)-azetidine-2-carboxylic acid (1 mol \%) & $\mathrm{rt}$ & 68 & 72 \\
\hline
\end{tabular}

${ }^{1}$ Isolated yields after column chromatography

${ }^{2}$ Determined by HPLC

rt, Room temperature

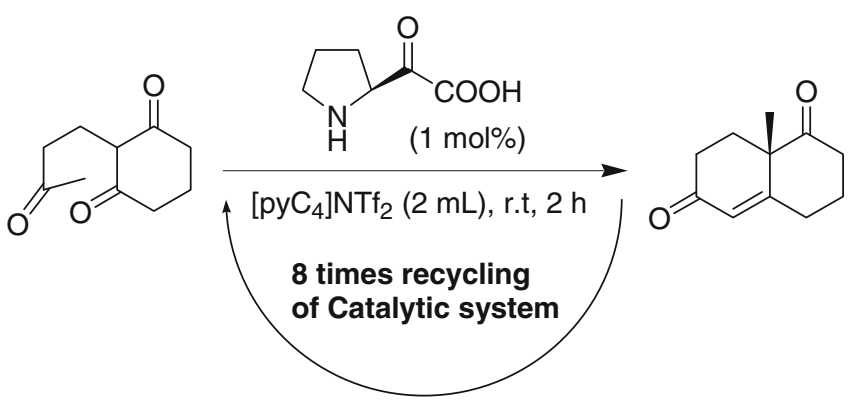

Scheme 4. Recycling parameters for Wieland-Miescher ketone $\mathbf{4}$ synthesis.

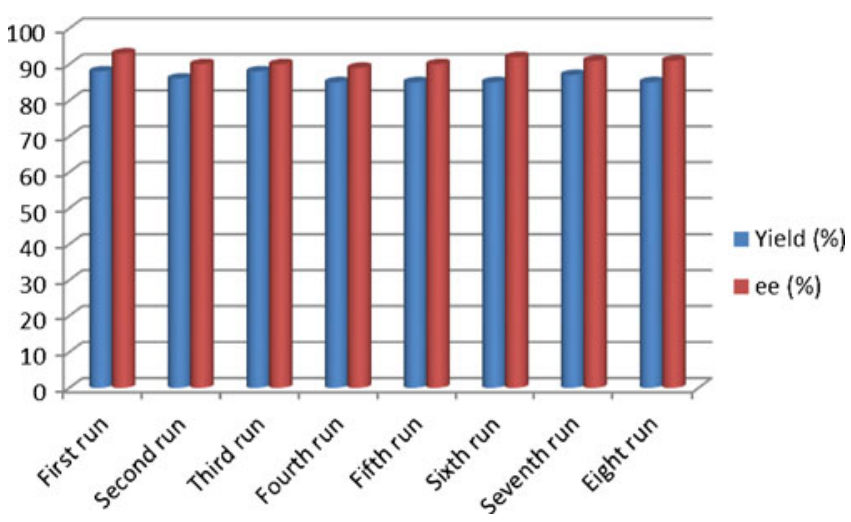

Figure 1. Recycling of $\left[\mathrm{pyC}_{4}\right] \mathrm{NTf}_{2} / \mathrm{L}$-proline catalytic system for Wieland-Miescher ketone 4.

\section{Conclusion}

We explored the application of L-proline for the synthesis of Wieland-Miescher ketone 4. In this report, we optimised reaction parameters such as time, temperature as well as quantity of catalyst for the synthesis of Wieland-Miescher ketone 4. As a result of our comprehensive study, L-proline ( $1 \mathrm{~mol} \%)$ was found suitable for the synthesis of Wieland-Miescher ketone 4 with good yield (88\%) and selectivity (93\% ee) at room temperature. Eight times recycling of the $\left[\mathrm{pyC}_{4}\right] \mathrm{NTf}_{2} / \mathrm{L}$ proline catalytic system for the synthesis of WielandMiescher ketone $\mathbf{4}$ is the major outcome of the proposed protocol.

\section{Supplementary information}

The electronic supporting information can be seen in www.ias.ac.in/chemsci.

\section{Acknowledgement}

The author is thankful to Sophisticated Analytical Instrument Facility, Panjab University, Chandigarh for NMR and HPLC characterization. 


\section{References}

1. (a) Eder U, Sauer G and Wiechert R 1971 Angew. Chem., Int. Ed. Engl. 10 496; (b) Bradshaw B and Bonjoch J 2012 Synlett 23 337; (c) Hajos Z G and Parrish D R 1973 J. Org. Chem. 38 3239; (d) List B 2002 Tetrahedron $\mathbf{5 8} 5573$

2. (a) Zhong G, Hoffmann T, Lerner R A, Danishefsky S and Barbas C F 1997 J. Am. Chem. Soc. 119 8131; (b) Davies S G, Sheppard R L, Smith A D and Thomson J E 2005 Chem. Commun. 30 3802; (c) Almaşi D, Alonso D A and Nájera C 2008 Adv. Synth. Catal. 3502467

3. Cheong P H Y and Houk K N 2005 Synthesis 9 1533

4. (a) Cheong $\mathrm{P} \mathrm{H} \mathrm{Y}$, Houk $\mathrm{K} \mathrm{N}$, Warrier J S and Hanessian S 2004 Adv. Synth. Catal. 346 1111; (b) Ahluwalia V K and Kidwai M 2004 In New trends in green chemistry (Netherlands: Springer) p. 118; (c) Buchschacher P, Fürst V and Gutzwiller J 1990 Org. Synth. 7 368; (d) Rajagopal D, Naraynana R and Swaminathan S 2001 Proc. Indian Acad. Sci. (Chem. Sci.) 113 197; (e) Narayanan R and Swaminathan S 1990 Indian J. Chem. B29 1401; (f) Rajagopal D, Rajagopalan K and Swaminathan S 1996 Tetrahedron: Asymmetry 7 2189; (g) Rajagopal D, Monib M S, Subramanian S and Swaminathan S 1999 Tetrahedron: Asymmetry 10 1631; (h) Harada
N, Sugioka T, Uda H and Kuriki T 1990 Synthesis 153

5. Buchschacher P, Cassal J M, Fuerst A and Meier W 1977 Helv. Chim. Acta $\mathbf{6 0} 2747$

6. (a) Gruttadauria M, Giacalone F and Noto R 2008 Chem. Soc. Rev. 37 1666; (b) Srivastava V 2013 J. Chem. 2013 1; (c) Srivastava V 2013 J. Chem. 2013 9; (d) Srivastava V 2012 Asymmetric Organocatalysis 1 2; (e) Srivastava V, Gaubert K, Pucheault M and Vaultier M, 2009 Chem. Cat. Chem. 1 94; (f) Srivastava V 2012 Asymmetric Organocatalysis 18

7. (a) Wilkes J S 2004 J. Mol. Catal. A: Chem. I 214 11; (b) Hardacre C, Holbrey J D, Nieuwenhuyzen M and Youngs T G A 2007 Acc. Chem. Res. 40 1146; (c) Vaultier M, Kirschning A and Singh V 2008 In Ionic liquids in synthesis (eds) P Wasserscheid and T Welton (Weinheim: Wiley-VCH) vol. 2, p. 488

8. Kondo K, Yamano T and Takemoto 1985 Makromol. Chem. 1861781

9. Agami C, Platzer N and Sevestre H 1987 Bull. Soc. Chim. Fr. 2358

10. Nozawaa M, Akitaa T, Hoshib T, Suzukib T and Hagiwara H 2007 Synlett 4661

11. (a) Ignat'ev N V, Barthen P, Kucheryna A, Willner $\mathrm{H}$ and Sartori P 2012 Molecules 17 5319; (b) Veron J, Joetger J M, Pucheault M and Vaultier M 2007 Tetrahedron Lett. 48 4055; (c) Varma R S and Namboodiri V V 2001 Pure Appl. Chem. 731309 